\title{
Pigeon peas as a supplement for lactating dairy cows fed corn silage-based diets
}

\author{
V. A. Corriher, ${ }^{* 1}$ G. M. Hill, ${ }^{*}$ J. K. Bernard, ${ }^{*}$ T. C. Jenkins, $†$ J. W. West, ${ }^{*}$ and B. G. Mullinix Jr.‡ \\ *Department of Animal and Dairy Science, University of Georgia, Tifton 31793 \\ †Department of Animal and Veterinary Science, Clemson University, Clemson SC 29634 \\ ‡Experimental Statistics, Texas A\&M University, Lubbock 79403
}

\section{ABSTRACT}

Holstein rumen-cannulated cows $[\mathrm{n}=7$; initial body weight $(\mathrm{BW}) 640.56 \pm 71.43 \mathrm{~kg}$ ] were fed a corn silage basal diet with 1 of 3 concentrates $(\mathrm{C}=$ control; P10 $=10 \%$ pigeon peas; $\mathrm{P} 20=20 \%$ pigeon peas). Cows were randomly assigned to treatments in a replicated $3 \times 3$ Latin square and individually fed using Calan gates. Each experimental period was $21 \mathrm{~d}$ with $7 \mathrm{~d}$ for adaption and $14 \mathrm{~d}$ for sample collection. Ruminal fluid samples were taken the last day of each experimental period and analyzed for $\mathrm{pH}$, ammonia, long-chain fatty acids, and volatile fatty acids (VFA). Consecutive a.m. and p.m. milk samples were taken during the last 2 wk of the 21-d period and analyzed for fat, protein, long-chain fatty acids, and somatic cell count. Dry matter intake $(\mathrm{kg} / \mathrm{d})$ was reduced during the second period and was greater for P10 diets. Milk protein was greater for cows fed P20 compared with P10. Energycorrected milk was greater for cows fed the control diet compared with P10. Treatment had no effect on milk yield. Ruminal fluid $\mathrm{pH}$ decreased over sampling times; however, $\mathrm{pH}$ remained at or above 5.5. Diets did not affect ruminal fluid $\mathrm{pH}$; however, $\mathrm{pH}$ was different for sampling periods. Ruminal ammonia decreased until 8 $\mathrm{h}$ postfeeding at which time it peaked consistent with changes in ammonia concentrations that usually peak 3 to $5 \mathrm{~h}$ postfeeding on diets high in plant proteins. Dietary treatments altered ruminal fluid VFA with reduced concentrations of acetate and greater concentrations of propionate for control diet, resulting in reduced acetate:propionate ratio. Isobutyrate exhibited an hour by treatment interaction, in which isobutyrate decreased until $8 \mathrm{~h}$ postfeeding and then tended to be greater for P10 than for other treatments. Animals fed the P10 diet had greater concentrations of ruminal isovalerate. Ruminal cis-9,trans-11 and trans-10,cis-12 conjugated linoleic acid (CLA) isomers were not af-

Received February 17, 2010.

Accepted May 26, 2010.

${ }^{1}$ Corresponding author: vacorriher@ag.tamu.edu fected by dietary treatments. The P10 diet had greatest ruminal synthesis of cis-9, trans-11, but control cows had greatest ruminal synthesis of trans-10,cis-12. Milk CLA isomers were similar among treatments. Trends were observed for greater cis-9,trans-11 and trans-10,cis-12 for the P10 diet. Pigeon peas may be used as a protein supplement in dairy diets without affecting milk production, dry matter intake, or ruminal environment when they replace corn and soybean meal.

Key words: dairy, pigeon pea, fatty acid, milk

\section{INTRODUCTION}

Pigeon pea [Cajanus cajan (L.)], a drought-tolerant legume, is an important grain crop grown in tropical and subtropical regions (Nene and Sheila, 1990). Pigeon peas typically contain $9.9 \%$ moisture, $19.5 \%$ protein, $1.3 \%$ fat, $65.5 \%$ carbohydrate, $1.3 \%$ fiber, $3.8 \%$ ash, $0.16 \% \mathrm{Ca}, 0.29 \% \mathrm{P}$, and $0.015 \% \mathrm{Fe}$ (Duke, 1981; DM basis). Steers fed pigeon peas or pearl millet grain supplements with Tifton 85 bermudagrass hay had greater apparent digestion of $\mathrm{CP}$ for pigeon pea diets (Hill et al., 2006). The ADG of yearling heifers tended to be greater when they were fed pigeon peas compared with corn/soybean meal, whole cottonseed, or corn gluten feed (Corriher et al., 2007).

Pigeon peas contain proteinase inhibitors and tannins, which have been shown to reduce performance of pigs and poultry (Visitpanich et al., 1985; Tangtaweewipat and Elliot, 1989). Nevertheless, pigeon peas could replace soybean meal and constitute approximately half the intake of growing sheep without adverse effects (Cheva-Isarakul, 1992). Oil in pigeon peas contains $5.7 \%$ linolenic acid, $51.4 \%$ linoleic, $6.3 \%$ trans-vaccenic, and $36.6 \%$ saturated fatty acids (Duke, 1981). Despite having only approximately $2 \%$ total fat, the high concentration of linoleic acid (51.4\%) suggests that pigeon peas could be an important dietary factor for increasing conjugated linoleic acid $(\mathbf{C L A})$ concentrations in ruminant products.

Dietary lipids are extensively altered by ruminal bacterial metabolism, and one of the major changes is 
Table 1. Composition of the different total diets for dairy cows

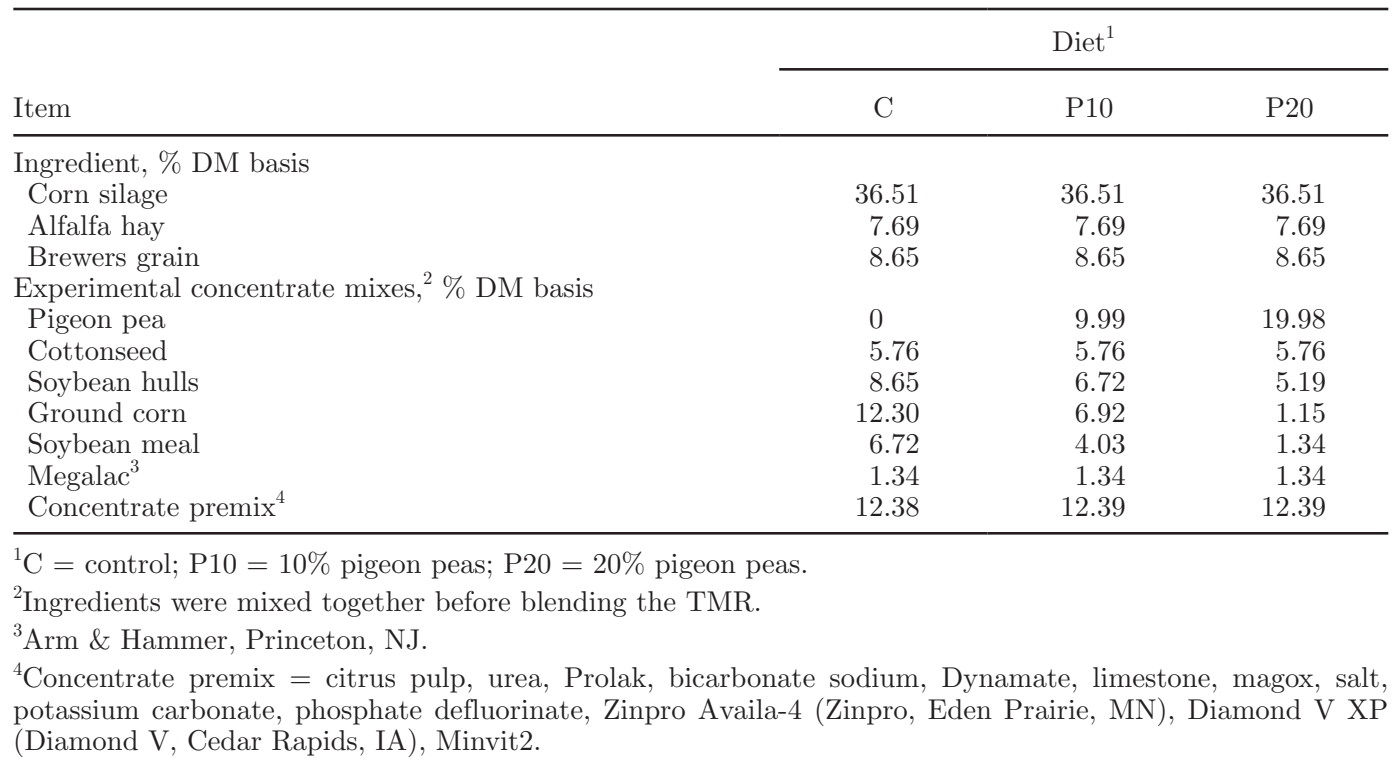

biohydrogenation of polyunsaturated fatty acids. Diet can markedly affect bacterial population and ruminal microbial processes; therefore, diet and nutrition may have major effects on fat content and fatty acid composition of milk in many species, including ruminants. Research indicates that changes in the ruminal environment will lead to changes in microbial activity that correspond to altered end-product formation. Because the ruminal environment is subject to change, it is possible that these changes will have an effect on CLA formation by ruminal microbial population (Martin and Jenkins, 2002).

Pigeon peas, which contain up to $60 \%$ unsaturated fatty acid, could increase the concentration of CLA in milk. Therefore, our objective was to determine the effect of pigeon pea supplementation on milk production and ruminal characteristics in dairy cows fed a TMR with 0,10 , and $20 \%$ pigeon peas.

\section{MATERIALS AND METHODS}

\section{Cows and Sampling Methods}

Seven primiparous ruminally cannulated Holstein cows $(640.6 \pm 71.4 \mathrm{~kg}$ of $\mathrm{BW})$ were used in a $3 \times$ 3 Latin square with 21-d periods. Cows were housed in a free-stall barn and averaged $89 \pm 6.7$ DIM and $40.1 \pm 4.0 \mathrm{~kg} / \mathrm{d}$ of milk at the beginning of the trial. Treatment diets consisted of 3 levels of pigeon peas, including 0 (control), 10\% (P10), or 20\% (P20) pigeon peas. Pigeon peas were incorporated into rations (Table 1) and individually fed once daily behind Calan doors (American Calan Inc., Northwood, NH). Treatment diets were balanced for $\mathrm{CP}$ and fiber content, and they were isocaloric and isonitrogenous. Each cow was offered each treatment for $21 \mathrm{~d}$, and ruminal fluid samples were taken on the last day of the experimental period and analyzed for $\mathrm{pH}$, ammonia, VFA, and long-chain fatty acids (LCFA). Cows were milked twice daily at approximately 0400 and $1500 \mathrm{~h}$. Consecutive a.m. and p.m. milk samples were taken from each cow the last 2 wk of the 21-d period and analyzed for fat, protein, SCC, and LCFA. Samples of diets and ingredients were taken every $14 \mathrm{~d}$ and frozen at $-20^{\circ} \mathrm{C}$ for subsequent analyses. All cattle were managed under procedures approved by the University of Georgia Animal Care and Use Committee Guidelines. Diets were mixed daily and individually fed to cows at $1200 \mathrm{~h}$ daily, with amounts of feed offered and refused recorded daily. Individual milk yield was recorded electronically (Alpro, DeLaval, Kansas City, MO) at each milking and summed for each day. Cows were trained to use Calan gate feeders (American Calan Inc.) and then fed supplement treatments.

\section{Chemical Analyses of Feeds and Samples}

Forage and silage samples were lyophilized, ground through a Wiley mill (1-mm screen), and stored at $-20^{\circ} \mathrm{C}$ for subsequent chemical analyses. Organic matter was measured as the weight loss following combustion for $8 \mathrm{~h}$ at $500^{\circ} \mathrm{C}$. Neutral detergent fiber and ADF were sequentially determined using an Ankom 200 fiber extractor (Ankom Technology, Fairport, NY) according to the method of Van Soest et al. (1991). Crude protein concentration was determined by the combustion 
Table 2. Mean DM chemical and fatty acid composition of the total diets for dairy cows

\begin{tabular}{|c|c|c|c|c|c|}
\hline \multirow[b]{2}{*}{ Item } & \multirow[b]{2}{*}{$\begin{array}{c}\text { Corn } \\
\text { silage }\end{array}$} & \multirow[b]{2}{*}{$\begin{array}{c}\text { Pigeon } \\
\text { peas }\end{array}$} & \multicolumn{3}{|c|}{ Diet $^{1}$} \\
\hline & & & $\mathrm{C}$ & P10 & P20 \\
\hline \multicolumn{6}{|c|}{ Chemical composition, \% DM basis } \\
\hline DM & 41.2 & 88.4 & 52.4 & 52.3 & 52.3 \\
\hline $\mathrm{CP}$ & 11.0 & 24.0 & 19.6 & 18.2 & 19.1 \\
\hline $\mathrm{NDF}$ & 26.6 & 12.8 & 28.3 & 26.3 & 24.9 \\
\hline $\mathrm{ADF}$ & 14.3 & 12.1 & 18.8 & 19.1 & 17.9 \\
\hline Total FA & 3.62 & 2.5 & 4.9 & 4.8 & 4.6 \\
\hline \multicolumn{6}{|c|}{ FA composition, $\mathrm{mg} / 100 \mathrm{mg}$ of $\mathrm{FA}$} \\
\hline $\mathrm{C} 14: 0$ & 0.70 & 0.02 & 2.02 & 5.16 & 2.20 \\
\hline C16:0 & 27.87 & 0.23 & 67.57 & 199.08 & 88.02 \\
\hline C18:0 & 3.85 & 0.043 & 12.51 & 28.71 & 12.03 \\
\hline $\mathrm{C} 18: 1$ & 25.09 & 0.75 & 8.89 & 15.47 & 13.99 \\
\hline C18:2 & 39.26 & 0.57 & 46.09 & 33.80 & 40.19 \\
\hline $\mathrm{C} 18: 3$ & 2.00 & 0.046 & 22.95 & 14.02 & 48.37 \\
\hline Others $^{2}$ & 1.23 & 0.019 & 7.01 & 5.30 & 5.70 \\
\hline Unidentified & 0.0 & 0.8 & 30.20 & 22.79 & 24.48 \\
\hline
\end{tabular}

${ }^{1} \mathrm{C}=$ control; $\mathrm{P} 10=10 \%$ pigeon peas; $\mathrm{P} 20=20 \%$ pigeon peas.

${ }^{2}$ Sum of C12:0, C15:0, C16:1, C17:0, C20:0, C21:0, and C22:0.

method using a Leco FP-2000 N analyzer (Leco Corp., St. Joseph, MI). On the last day of the experimental period, ruminal fluid samples were collected at $-2,0,2$, $4,6,8$, and $10 \mathrm{~h}$ postfeeding. Approximately $50 \mathrm{~mL}$ of ruminal fluid was collected and strained through 3 layers of cheesecloth, analyzed for $\mathrm{pH}$ and ammonia, and stored frozen for subsequent analyses of LCFA. A 40-mL subsample was strained through 3 layers of cheesecloth and immediately mixed with $10 \mathrm{~mL}$ of metaphosphoric acid $(25 \% \mathrm{wt} / \mathrm{vol})$. The sample was frozen for later analyses of VFA (Erwin et al., 1961). These samples were later thawed and centrifuged at $10,000 \times g$ for 10 min and the supernatant collected for VFA analysis using a Hewlett-Packard gas chromatograph (GLC; Varian 3400 Instrument Group, Hewlett-Packard Company, Avondale, PA) fitted with a nitroterephthalic acid modified polyethylene glycol megabore column (30 $\mathrm{m} \times$ $0.53 \mathrm{~mm}$ i.d. with $1-\mu \mathrm{m}$ film; J\&W Scientific, Folsom, $\mathrm{CA}$ ). Initial oven temperature was $130^{\circ} \mathrm{C}$ for $7 \mathrm{~min}$, and helium flow was $7 \mathrm{~mL} / \mathrm{min}$. The oven temperature was increased at the rate of $2.9^{\circ} \mathrm{C} / \mathrm{min}$ over $7 \mathrm{~min}$ to a final temperature of $150^{\circ} \mathrm{C}$. Helium flow was increased to 9 $\mathrm{mL} / \mathrm{min}$. Airflow was $400 \mathrm{~mL} / \mathrm{min}$, and hydrogen flow was $29 \mathrm{~mL} / \mathrm{min}$. Heptanoic acid was used as an internal standard.

Total fatty acid percentage and fatty acid profile were determined for forage and supplement samples. Fatty acids were methylated following methods described by Park and Goins (1994) and separated by GLC procedures, as described by Duckett et al. (2002). For wet tissue lipid, $1 \mathrm{~g}$ of milk lipids was extracted. Milk lipid extracts containing approximately $2 \mathrm{mg}$ of total lipids, based on the calculated percentage lipids on a wet tissue basis, were transmethylated (Park and Goins, 1994). Fatty acid methyl esters were analyzed using an HP6850 (Hewlett-Packard, San Fernando, CA) gas chromatograph equipped with an HP7673A (HewlettPackard) automatic sampler. Separations were accomplished using a 100-m Sp2560 (Supelco, Bellefonte, PA) capillary column $(0.25 \mathrm{~mm}$ i.d. and $0.20-\mu \mathrm{m}$ film thickness) according to Duckett et al. (2002). Column oven temperature increased from 150 to $160^{\circ} \mathrm{C}$ at $1^{\circ} \mathrm{C} / \mathrm{min}$,

Table 3. Dairy cow DMI and milk composition when fed supplemental pigeon peas

\begin{tabular}{|c|c|c|c|c|c|}
\hline \multirow[b]{2}{*}{ Item } & \multicolumn{3}{|c|}{$\operatorname{Diet}^{1}$} & \multirow[b]{2}{*}{$\mathrm{SE}$} & \multirow[b]{2}{*}{$P<$} \\
\hline & $\mathrm{C}$ & $\mathrm{P} 10$ & P20 & & \\
\hline DMI, $\mathrm{kg} / \mathrm{d}$ & 22.92 & 23.38 & 22.87 & 1.40 & 0.04 \\
\hline Fat, $\%$ & 3.24 & 2.92 & 3.29 & 0.12 & NS \\
\hline Protein, \% & $2.83^{\mathrm{a}}$ & $2.57^{\mathrm{b}}$ & $2.90^{\mathrm{a}}$ & 0.10 & 0.05 \\
\hline ECM, \% & $35.02^{\mathrm{a}}$ & $29.41^{\mathrm{b}}$ & $33.37^{\mathrm{a}}$ & 3.67 & 0.02 \\
\hline $\operatorname{lnSCC}{ }^{2}$ & 1.72 & 1.60 & 1.38 & 0.10 & 0.07 \\
\hline
\end{tabular}




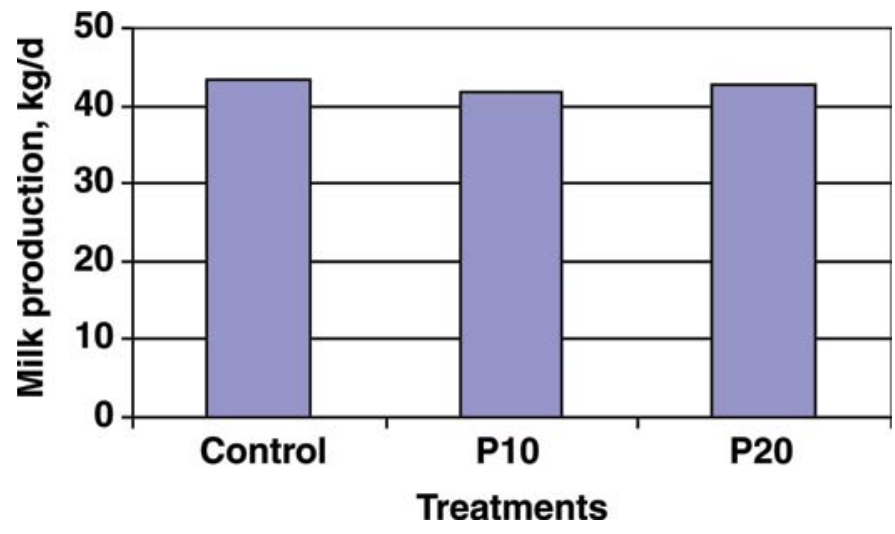

Figure 1. Milk production of dairy cows fed supplemental pigeon peas by dietary treatments $(P<0.34)$. P10 $=10 \%$ pigeon peas; $\mathrm{P} 20=$ $20 \%$ pigeon peas. Color version available in the online PDF.

from 160 to $167^{\circ} \mathrm{C}$ at $0.2^{\circ} \mathrm{C} / \mathrm{min}$, from 167 to $225^{\circ} \mathrm{C}$ at $1.5^{\circ} \mathrm{C} / \mathrm{min}$, and then held at $225^{\circ} \mathrm{C}$ for $16 \mathrm{~min}$. The injector and detector were maintained at $250^{\circ} \mathrm{C}$, with a sample injection volume of $1 \mu \mathrm{L}$. Hydrogen was the carrier gas at a flow rate of $1 \mathrm{~mL} / \mathrm{min}$. Individual fatty acids were identified by comparison of retention times with standards (Sigma, St. Louis, MO; Supelco; Matreya, Pleasant Gap, PA). Fatty acids were quantified by incorporating an internal standard, methyl heptacosanoic (C27:0) acid into each sample during methylation and expressed as $\mathrm{g} / 100 \mathrm{~g}$ of tissue.

\section{Statistical Analysis}

Data were statistically analyzed as a replicated $3 \times$ 3 Latin square using the MIXED procedure of SAS (SAS Institute, 2003) with animal as the experimental unit and dietary treatment and experimental period blocked. Ruminal $\mathrm{pH}$, ammonia, and VFA data were subjected to ANOVA using PROC MIXED procedures

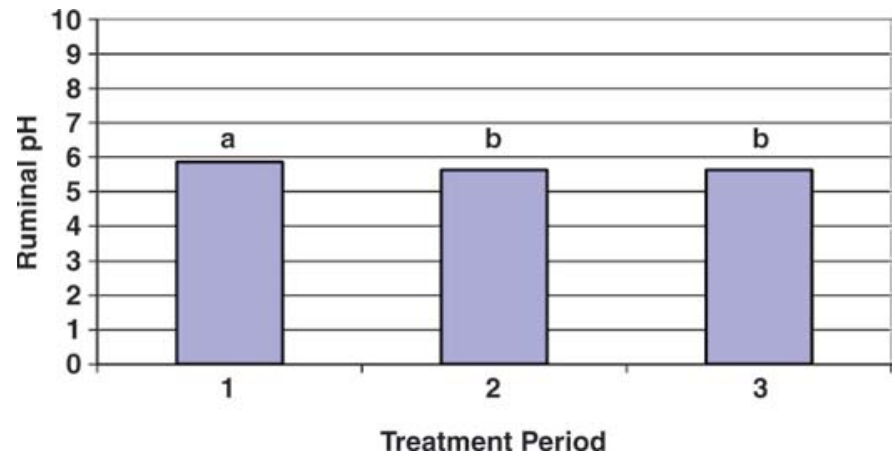

Figure 2. Ruminal fluid $\mathrm{pH}$ of dairy cows fed supplemental pigeon peas by treatment periods $(P<0.0008$; $\mathrm{SE}=0.07)$. ${ }^{\mathrm{a}, \mathrm{b}}$ Means with different letters differ $(P<0.05)$. Color version available in the online PDF

Journal of Dairy Science Vol. 93 No. 11, 2010

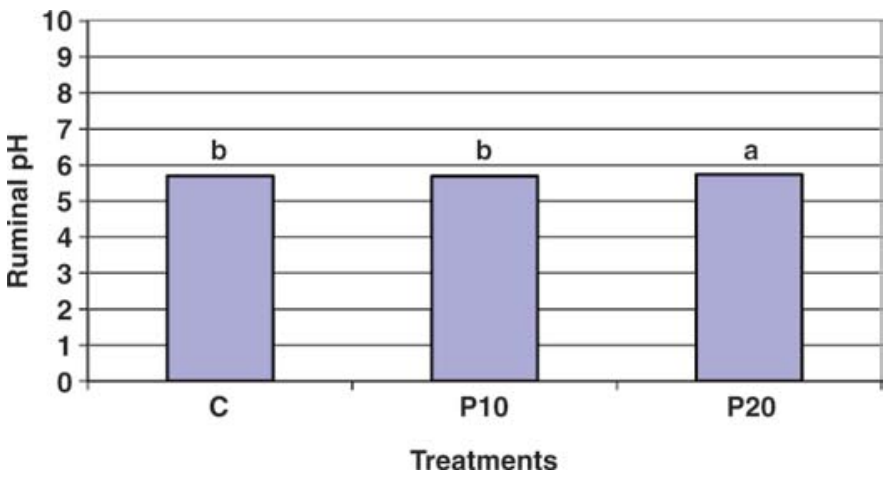

Figure 3. Ruminal fluid $\mathrm{pH}$ of dairy cows fed supplemental pigeon peas by dietary treatments $(P<0.59 ; \mathrm{SE}=0.07) . \mathrm{C}=$ control; $\mathrm{P} 10$ $=10 \%$ pigeon peas; $\mathrm{P} 20=20 \%$ pigeon peas. ${ }^{\mathrm{a}, \mathrm{b}}$ Means with different letters differ $(P<0.05)$. Color version available in the online PDF. Color version available in the online PDF.

of SAS (SAS Institute, 2003). The model included cow, hour, period, treatment, hour $\times$ treatment, and error.

\section{RESULTS AND DISCUSSION}

Pigeon peas replaced corn and soybean meal in dairy diets at 2 levels $(\mathrm{P} 10=10 \%$ pigeon peas and P20 $=20 \%$ pigeon peas; Tables 1 and 2). Experimental diets contained similar concentrations of $\mathrm{CP}$ and NDF (Table 2). The P20 diet contained slightly lower concentrations of NDF and ADF, reflecting the lower fiber and greater starch concentrations of the pigeon peas. Average concentrations of DM, CP, and NDF for experimental diets were $52.3,18.9$, and $26.5 \%$ of $\mathrm{DM}$, respectively. Concentrations of NDF were adequate to maintain rumen function. Pigeon peas are known to have antinutritional factors such as proteinase inhibitors and tannins. The proteinase inhibitors are those that inhibit trypsin and chymotrypsin activities. This can lead to reduced protein availability and amino acid absorption from the small intestine (Dixon and Hosking, 1992). Tannins are bitter plant polyphenols that either

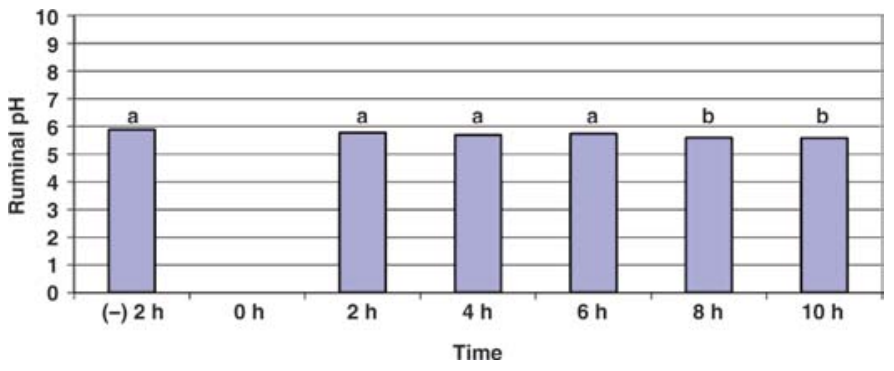

Figure 4. Effect of sampling time on ruminal fluid $\mathrm{pH}$ relative to time of feeding for dairy cows fed supplemental pigeon peas $(P<$ 0.002; $\mathrm{SE}=0.08)$. ${ }^{\mathrm{a}, \mathrm{b}}$ Means with different letters differ $(P<0.05)$. Color version available in the online PDF. 


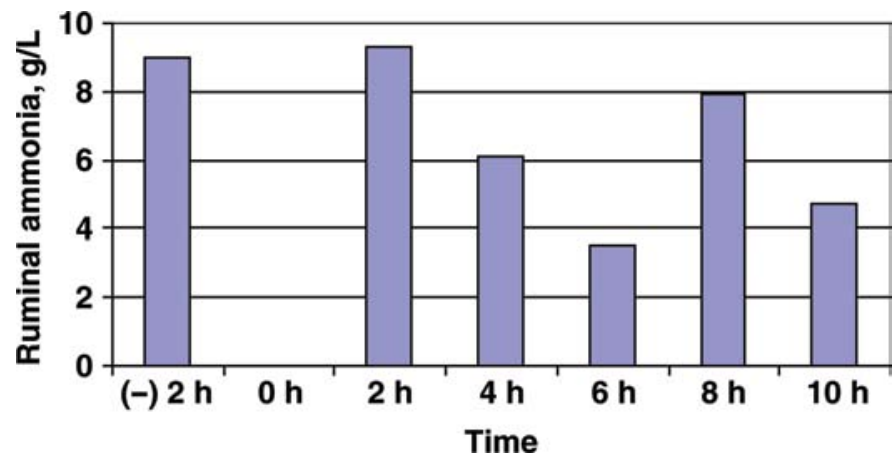

Figure 5. Effect of sampling time on ruminal fluid ammonia concentration relative to time of feeding for dairy cows fed supplemental pigeon peas $(\mathrm{g} / \mathrm{L} ; P<0.002 ; \mathrm{SE}=1.07)$. Color version available in the online PDF.

bind and precipitate or shrink proteins, amino acids, and alkaloids. Tannins may reduce intake by decreasing palatability and by negatively affecting digestion (Reed, 1995). Pigeon peas have been shown to reduce growth performance of pigs and poultry as a result of proteinase inhibitors and tannins (Visitpanich et al., 1985; Tangtaweewipat and Elliot, 1989). No adverse effects were seen when pigeon peas replaced soybean meal and constituted approximately half the intake of growing sheep (Cheva-Isarakul, 1992). Dry matter intake for treatment periods 1,2 , and 3 in the current study were $23.39,22.76$, and $23.20 \mathrm{~kg} / \mathrm{d}$, respectively. The DMI $(\mathrm{kg} / \mathrm{d})$ was reduced during the second period, and was greater for P10 diets $(P<0.05$; Table 3$)$. Increasing pigeon pea supplementation did not decrease DMI for cows.

The SCC in milk samples tended to be greater for cows on the control diet compared with the P10 diet $(P>0.10$; Table 3$)$. General agreement rests on the values of $<100,000$ cells $/ \mathrm{mL}$ for uninfected cows, and $>300,000$ cells $/ \mathrm{mL}$ for cows infected with significant pathogens (Smith, 1996). During treatment periods, SCC was never greater than 300,000 cells/mL; therefore,

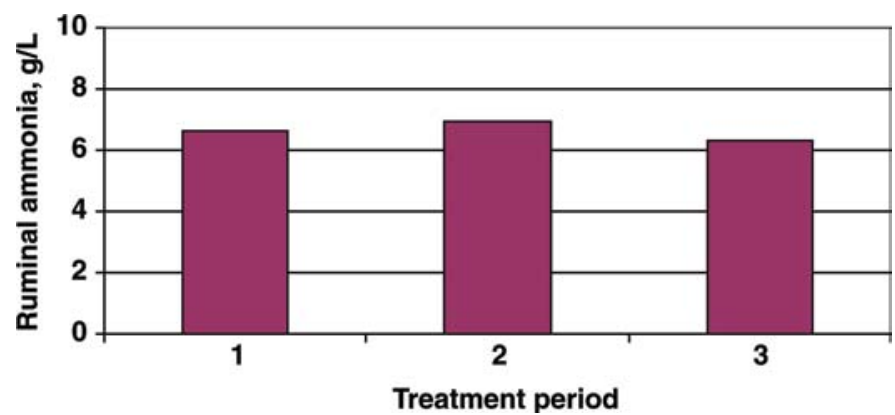

Figure 6. Effect of treatment period on ruminal fluid ammonia of dairy cows fed supplemental pigeon peas (g/L; $P<0.85 ; \mathrm{SE}=0.08$ ). Color version available in the online PDF. the possible occurrence of a pathogen never affected experimental results. Diets do not generally affect SCC, but environment may affect SCC in dairy cows. The environment of tester animals was never altered during the experimental period. Milk protein percentage was greater for cows on P20 compared with P10 $(P<0.05$; Table 3). Energy-corrected milk accounts for the true protein content of milk and it was calculated using the equation: $\mathrm{ECM}=(0.3246 \times \mathrm{kg}$ of milk $)+(12.86 \times \mathrm{kg}$ of fat $)+(7.04 \times \mathrm{kg}$ of protein $)$. Milk ECM was greater for cows when on the control diet compared with the P10 diet $(P<0.05$; Table 3$)$. The cows fed the control diet used more tissue energy to support milk production. Treatment had no effect on milk production $(P>$ 0.10 ; Figure 1), but control cows tended to have greater milk production.

Figures 2, 3, and 4 show effects of treatment period, diet, and sampling time on ruminal fluid $\mathrm{pH}$. Ruminal fluid $\mathrm{pH}$ decreased during the 12 -h period of sampling $(P<0.01$; Figure 4$)$; however, the $\mathrm{pH}$ never decreased below 5.5. Treatment did not affect $\mathrm{pH}(P>0.10$; Figure 3$)$. With typical diets fed to lactating dairy cows, the $\mathrm{pH}$ of ruminal fluid is usually between 5.5 and 6.5 , whereas high forage diets support a ruminal fluid $\mathrm{pH}$ in the range from 6.2 to 7 . Inclusion of pigeon peas in the TMR did not have an effect on ruminal $\mathrm{pH}$; it remained between 5.5 and 6.5 throughout the sampling interval. Cellulose digestion is inhibited when $\mathrm{pH}$ decreases below 6 (Owens and Goetsch, 1988). Depressed fiber digestion has been attributed to low ruminal $\mathrm{pH}$ associated with feeding high levels of concentrate (Orskov and Fraser, 1975). They attributed this to the sensitivity of cellulolytic microbes to low ruminal $\mathrm{pH}$. Depressed starch digestion has been attributed to an increased rate of flow through the rumen or small intestine, providing less time for digestion and absorption of starch (Zinn and Owens, 1980). With continuous feeding of high concentrate diets, animals tend to consume many meals per day and ruminal $\mathrm{pH}$ never increases sufficiently to

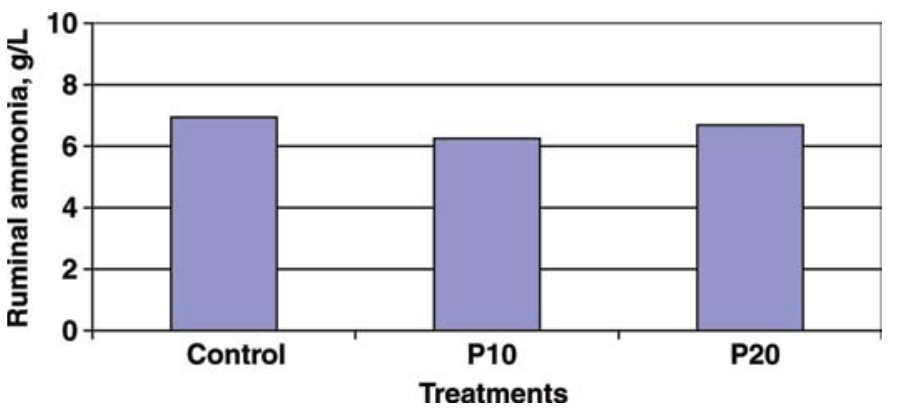

Figure 7. Ruminal fluid ammonia of dairy cows fed supplemental pigeon peas by dietary treatments $(\mathrm{g} / \mathrm{L} ; P<0.80 ; \mathrm{SE}=0.08)$. $\mathrm{P} 10=$ $10 \%$ pigeon peas; $\mathrm{P} 20=20 \%$ pigeon peas. Color version available in the online PDF. 
Table 4. Ruminal fluid VFA (as \% of total VFA) of dairy cows fed varying levels of supplemental pigeon peas

\begin{tabular}{lccccc}
\hline & \multicolumn{5}{c}{ Diet $^{1}$} \\
\cline { 2 - 4 } Ruminal VFA & $\mathrm{C}$ & $\mathrm{P} 10$ & $\mathrm{P} 20$ & $\mathrm{SE}$ & $P<$ \\
\hline Acetate & $0.60^{\mathrm{b}}$ & $0.61^{\mathrm{a}}$ & $0.61^{\mathrm{a}}$ & 0.004 & 0.03 \\
Propionate & $0.24^{\mathrm{a}}$ & $0.23^{\mathrm{b}}$ & $0.23^{\mathrm{b}}$ & 0.005 & 0.02 \\
Isobutyrate & - & - & - & - & - \\
Butyrate & 0.112 & 0.114 & 0.114 & 0.002 & 0.85 \\
Isovalerate & $0.014^{\mathrm{b}}$ & $0.016^{\mathrm{a}}$ & $0.014^{\mathrm{b}}$ & 0.0008 & 0.05 \\
Valerate & 0.021 & 0.021 & 0.020 & 0.0008 & 0.29 \\
Total, mMol & 95.84 & 98.50 & 100.18 & 1.26 & 0.57 \\
Acetate:propionate & $2.55^{\mathrm{b}}$ & $2.74^{\mathrm{a}}$ & $2.66^{\mathrm{a}}$ & 0.19 & 0.03 \\
\hline a,b Means within a row with different superscript letters differ $(P<0.05)$. & & \\
${ }^{1} \mathrm{C}=$ control; P10 $=10 \%$ pigeon peas; P20 $=20 \%$ pigeon peas. & & \\
${ }^{2}$ Isobutyrate exhibited an hour by treatment interaction; see Table 5. No other hour by treatment interactions \\
occurred.
\end{tabular}

initiate substantial cellulose digestion. The time after feeding when $\mathrm{pH}$ is lowest is usually between 0.5 and $4 \mathrm{~h}$ after a meal (Zinn and Owens, 1980). The lowest $\mathrm{pH}$ in the present study occurred at 8 to $10 \mathrm{~h}$ after the a.m. feeding (Figure 4); however, $\mathrm{pH}$ did decrease at 4 $\mathrm{h}$ postfeeding. This decrease in $\mathrm{pH}$ reflects the balance between rates of acid production, input of dietary buffers from saliva, and presence or release of buffers or bases from the feed.

When $\mathrm{pH}$ falls from 7 to between 5 and 5.5, many ruminal microbes cease growing, despite an ability to survive even greater concentrations of $\mathrm{H}^{+}$. Most acids, such as lactic acid, that inhibit microbes at high concentrations are more effective at high concentrations and when $\mathrm{pH}$ is low. If microbes are inhibited by $\mathrm{pH}$, a reduced $\mathrm{pH}$ could ultimately decrease biohydrogenation in the rumen. Decreased rumen $\mathrm{pH}$ often results in bacterial population shifts and consequent changes in the pattern of fermentation end-products (Van Soest, 1994). Leat et al. (1977) provided evidence showing that changes in ruminal bacterial populations are associated with modifications in the biohydrogenation pathways consistent with the altered trans-octadecenoic acid profile found in ruminal digesta and tissue lipids.

Figures 5, 6, and 7 show effects of sampling time, treatment period, and diet on ruminal fluid ammonia. Ruminal ammonia decreased linearly during the first $6 \mathrm{~h}$ postfeeding, but it increased at $8 \mathrm{~h}$ postfeeding to concentrations similar to those at $2 \mathrm{~h}$ before feeding (Figure 5). Ammonia concentrations usually peak about 1 to $2 \mathrm{~h}$ after a meal, whereas in diets high in plant proteins, high-level peaks are usually at 3 to 5 $\mathrm{h}$ postfeeding. Ammonia concentrations increased $2 \mathrm{~h}$ postfeeding and decreased from the $2 \mathrm{~h}$ concentration at 4 and $6 \mathrm{~h}$ postfeeding. At $8 \mathrm{~h}$ postfeeding, a second increase in ammonia concentration was observed, which probably resulted from a second meal taken by the cows after they returned from the $1500 \mathrm{~h}$ milking. Ammonia disappears from the rumen pool because of uptake by microbes, absorption through the rumen wall, and flushing to the omasum. Changes in any of these factors will alter the ammonia concentration in the rumen. The decrease in ammonia can be attributed to an increase in ammonia uptake by microbes or to an

Table 5. Isobutyrate $(\%$ of total VFA) $\times$ treatment interaction in ruminal fluid of dairy cows fed supplemental pigeon peas ${ }^{1}$

\begin{tabular}{|c|c|c|c|c|}
\hline \multirow[b]{2}{*}{ Sample time } & \multicolumn{3}{|c|}{ Diet $^{2}$} & \multirow[b]{2}{*}{$\mathrm{SE}$} \\
\hline & $\mathrm{C}$ & $\mathrm{P} 10$ & P20 & \\
\hline$-2 \mathrm{~h}$ & 0.01 & 0.01 & 0.008 & 0.002 \\
\hline $0 \mathrm{~h}^{3}$ & - & - & - & - \\
\hline $2 \mathrm{~h}$ & 0.008 & 0.01 & 0.007 & 0.002 \\
\hline $4 \mathrm{~h}$ & 0.008 & 0.007 & 0.008 & 0.002 \\
\hline $6 \mathrm{~h}$ & 0.005 & 0.005 & 0.006 & 0.002 \\
\hline $8 \mathrm{~h}$ & 0.003 & 0.004 & 0.007 & 0.002 \\
\hline $10 \mathrm{~h}$ & 0.004 & 0.008 & 0.006 & 0.002 \\
\hline
\end{tabular}

${ }^{1}$ Sampling time $\times$ treatment interaction $(P<0.01)$.

${ }^{2} \mathrm{C}=$ control; $\mathrm{P} 10=10 \%$ pigeon peas; $\mathrm{P} 20=20 \%$ pigeon peas.

${ }^{3} 0 \mathrm{~h}=$ time of feeding; no samples were taken at $0 \mathrm{~h}$. 
Table 6. Ruminal fluid VFA (as \% of total VFA) at different sampling times relative to feeding for dairy cows fed supplemental pigeon peas

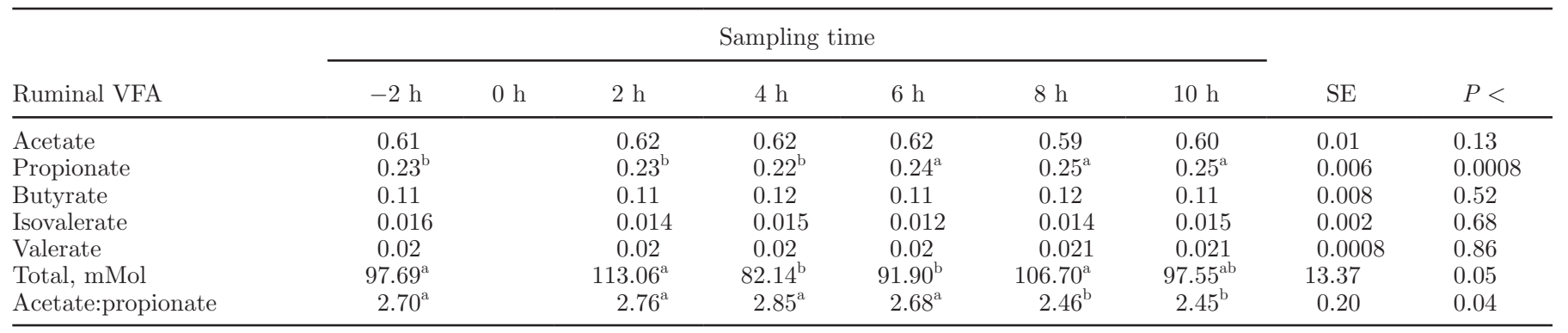

${ }^{\mathrm{a}, \mathrm{b}}$ Means within a row with different superscript letters differ $(P<0.05)$.

increase in microbe numbers. An increase in microbe numbers could modify the biohydrogenation pathways within the rumen.

Volatile fatty acids are produced by specific microbial pathways and absorbed continually from the rumen. Ruminal concentrations represent the balance between rates of production and removal for each VFA, as well as their interconversions. Total ruminal VFA were affected by dietary treatments $(P<0.05$; Table 4). Acetate was greater in ruminal fluid when cows were fed pigeon peas at both $10 \%$ and $20 \%$. The control diet resulted in the greatest concentration of propionate, leading to a reduced acetate:propionate ratio. The control diet resulted in the lowest amount of butyrate but the greatest concentrations of valerate. The acetate:propionate ratio was greatest $(P<0.05$; Table 4) for the P10 diet and did not fall below 2.5. An acetate:propionate ratio below 2.5 has been associated with milk fat depression in lactating dairy cows (Woodford et al., 1986), a syndrome that has been attributed to increased ruminal synthesis of 18:1 trans-10 (Griinari et al., 1998) and CLA trans-10,cis-12 (Baumgard et al., $2000)$. The P10 diet resulted in greater concentrations of ruminal isovalerate $(P<0.05$; Table 4$)$. Isobutyrate exhibited a sampling time $\times$ treatment interaction $(P$ $<0.05$; Table 5). The control diet resulted in the lowest levels of isobutyrate, regardless of sampling time in relation to feeding.

The ruminal concentration of propionate increased with time following feeding $(P<0.01$; Table 6$)$. The VFA concentrations were not different by sampling time $(P>0.10)$. The acetate:propionate ratio decreased linearly from $4 \mathrm{~h}$ postfeeding to $10 \mathrm{~h}$ postfeeding $(P<$ $0.05)$. The changes in $\mathrm{pH}$ and ruminal ammonia occurring 1 to $2 \mathrm{~h}$ postfeeding and then again at $8 \mathrm{~h}$ postfeeding may have resulted in similar changes in ruminal VFA synthesis.

Trans-vaccenic acid (C18:1 trans-11; TVA) was not affected by dietary treatments (Table $7 ; P>0.10$ ). The cis-9,trans-11 and trans-10,cis-12 CLA isomers were not different among dietary treatments $(P>0.10$; Table 8$)$. The increase in ruminal concentrations of cis-9,trans- 11 is reflective of greater concentrations of linoleic acid found in pigeon peas (Table 2). Trans-vaccenic acid was not different among sampling times $(P>0.10$; Table 9). However, ruminal concentrations of TVA increased linearly from $2 \mathrm{~h}$ postfeeding to $6 \mathrm{~h}$ and then decreased linearly. The cis-9,trans-11 increased linearly from $2 \mathrm{~h}$

Table 7. Selected fatty acid composition (\% of total fatty acids) of ruminal fluid of dairy cows fed varying levels of supplemental pigeon peas

\begin{tabular}{|c|c|c|c|c|c|}
\hline \multirow[b]{2}{*}{ Long-chain fatty acid } & \multicolumn{3}{|c|}{$\operatorname{Diet}^{1}$} & \multirow[b]{2}{*}{$\mathrm{SE}$} & \multirow[b]{2}{*}{$P<$} \\
\hline & $\mathrm{C}$ & $\mathrm{P} 10$ & P20 & & \\
\hline $\mathrm{C} 14$ & 1.93 & 2.38 & 2.16 & 0.30 & 0.06 \\
\hline C14:1 & 3.02 & 3.46 & 3.62 & 0.40 & 0.31 \\
\hline C16 & 30.65 & 31.11 & 30.83 & 0.57 & 0.74 \\
\hline C16:1 & 0.41 & 0.43 & 0.54 & 0.07 & 0.08 \\
\hline C18:0 & 40.99 & 41.63 & 41.09 & 0.90 & 0.86 \\
\hline C18:1 trans -11 & $4.43^{\mathrm{a}}$ & $4.80^{\mathrm{a}}$ & $3.96^{\mathrm{b}}$ & 0.46 & 0.04 \\
\hline C18:1 cis-9 & 6.74 & 5.63 & 6.20 & 0.74 & 0.34 \\
\hline cis-9,trans-11 & 0.21 & 0.24 & 0.22 & 0.04 & 0.74 \\
\hline trans-10, cis- 12 & 0.30 & 0.23 & 0.23 & 0.11 & 0.74 \\
\hline Total, mg/g & 22.33 & 21.81 & 21.64 & 1.45 & 0.94 \\
\hline
\end{tabular}

${ }^{\mathrm{a}, \mathrm{b}}$ Means within a row with different superscript letters differ $(P<0.05)$.

${ }^{1} \mathrm{C}=$ control; $\mathrm{P} 10=10 \%$ pigeon peas; $\mathrm{P} 20=20 \%$ pigeon peas. 
Table 8. Fatty acid composition (\% of total fatty acids) in ruminal fluid of dairy cows fed supplemental pigeon peas

\begin{tabular}{|c|c|c|c|c|c|c|c|c|c|}
\hline Long-chain fatty acid & \multicolumn{7}{|c|}{ Sampling time } & $\mathrm{SE}$ & $P<$ \\
\hline $\mathrm{C} 14$ & 2.30 & & 2.01 & 1.97 & 2.14 & 2.11 & 2.42 & 0.31 & 0.46 \\
\hline C16 & 29.66 & & 31.85 & 31.37 & 31.02 & 30.10 & 31.15 & 0.70 & 0.12 \\
\hline C16:1 & 0.50 & & 0.59 & 0.43 & 0.42 & 0.46 & 0.37 & 0.09 & 0.37 \\
\hline C18:0 & 41.40 & & 40.89 & 40.82 & 38.84 & 45.04 & 40.43 & 1.25 & 0.03 \\
\hline trans -10, cis- 12 & 0.20 & & 0.22 & 0.20 & 0.42 & 0.26 & 0.22 & 0.13 & 0.66 \\
\hline Total, mg/g & 24.63 & & 20.04 & 23.62 & 21.45 & 21.67 & 20.17 & 2.01 & 0.56 \\
\hline
\end{tabular}

${ }^{\mathrm{a}, \mathrm{b}}$ Means within a row with different superscript letters differ $(P<0.05)$.

postfeeding to $6 \mathrm{~h}$ and then decreased linearly. The trans-10, cis-12 increased from $2 \mathrm{~h}$ postfeeding to $4 \mathrm{~h}$ and then peaked at $8 \mathrm{~h}$.

Concentrations of trans-10, cis-12 CLA increase under certain dietary conditions, which may include feeding high levels of unsaturated fatty acids (Bauman and Griinari, 2001). The 2 main CLA isomers (cis-9,trans-11 and trans-10, cis-12) in milk fat were not different among treatments in the current trial $(P>0.10$; Table 9$)$. The trans-10, cis-12 CLA isomer inhibits the activity of $\Delta^{9}$ desaturase (Lee et al., 1998; Bretillon et al., 1999), ultimately reducing endogenous synthesis of cis-9,trans-11 CLA. An increase in trans-10, cis-12 could have resulted in the decrease in cis-9,trans-11 in the P10 and P20 diets (Table 9). Under certain dietary conditions, such as high concentrate, low fiber diets, the profile of CLA can be altered so the concentration of the trans-10,cis-12 isomer increases in milk fat (Griinari et al., 1999). Diets low in roughage decreased ruminal lipolysis and biohydrogenation (Latham et al., 1972; Gerson and King, 1985). Therefore, it has been suggested that the main ruminal biohydrogenating bacteria are cellulolytic (Latham et al., 1972; Harfoot and Hazlewood, 1997). In addition, Griinari et al. (1998) demonstrated that an altered rumen environment induced by feeding high concentrate, low fiber diets is associated with a change in the trans-octadecenoic acid profile of milk fat. In this situation, trans-10 octadecenoic acid replaced trans-11 C18:1 as the predominant trans-C18:1 isomer in milk fat. Further evidence in support of a specific bacterial cis-9, trans-10 isomerase is provided by observations that low fiber diets increase the proportion of trans-10, cis-12 CLA isomer in milk fat (Griinari et al., 1999). The diet is known to strongly influence the CLA content of milk and includes feedstuffs such as pasture, conserved forages, plant seed oils, cereal grains, marine oils and feeds, and animal fat.

Studies with lactating dairy cows have demonstrated that even in herds in which all cows were managed similarly and fed the same diet, there may still be a 3 -fold variation in the milk fat content of CLA (Jiang et al., 1996; Kelly et al., 1998a,b). These results suggest that it may be possible to see a difference in LCFA if the amount of pigeon peas was increased in the diet well above $20 \%$. The inclusion rates of pigeon peas at $10 \%$ and $20 \%$ of the diets were apparently too low to effect significant differences in LCFA in milk or in the rumen environment. Additional research is needed to

Table 9. Fatty acid composition (\% of total fatty acids) in milk of dairy cows fed supplemental pigeon peas

\begin{tabular}{lrrrrr}
\hline & \multicolumn{5}{c}{ Diet $^{1}$} \\
\cline { 2 - 4 } Long-chain fatty acid & \multicolumn{1}{c}{$\mathrm{C}$} & $\mathrm{P} 10$ & $\mathrm{P} 20$ & SE & $P<$ \\
\hline C14 & 10.97 & 10.64 & 10.57 & 0.35 & 0.48 \\
C14:1 & 0.82 & 0.75 & 0.73 & 0.05 & 0.15 \\
C16 & 33.90 & 34.99 & 36.04 & 1.35 & 0.29 \\
C16:1 & 1.81 & 2.40 & 1.70 & 0.58 & 0.44 \\
C18 & 18.76 & 12.36 & 13.05 & 4.41 & 0.29 \\
C18:1 trans-11 & 1.99 & 1.81 & 1.58 & 0.28 & 0.33 \\
C18:1 cis-9 & 12.10 & 10.97 & 11.34 & 1.90 & 0.83 \\
cis-9, trans-11 & 0.48 & 0.78 & 0.57 & 0.19 & 0.29 \\
trans-10, cis-12 & 0.25 & 0.65 & 0.33 & 0.17 & 0.06 \\
\hline
\end{tabular}

${ }^{1} \mathrm{C}=$ control; $\mathrm{P} 10=10 \%$ pigeon peas; $\mathrm{P} 20=20 \%$ pigeon peas. 
evaluate the effect of higher levels of pigeon peas on the rumen environment and the concentration of CLA in muscle, subcutaneous fat, and milk.

\section{REFERENCES}

Bauman, D. E., and J. M. Griinari. 2001. Regulation and nutritional manipulation of milk fat: low-fat milk syndrome. Livest. Prod. Sci. 70:15-29.

Baumgard, L. H., B. A. Corl, D. A. Dwyer, A. Saebo, and D. E. Bauman. 2000. Identification of the conjugated linoleic acid isomer that inhibits milk fat synthesis. Am. J. Physiol. Regul. Integr. Comp. Physiol. 278:R179-R184.

Bretillon, L., J. M. Chardigny, S. Gregoire, O. Berdeaux, and J. L. Sebedio. 1999. Effects of conjugated linoleic acid isomers on the hepatic microsomal desaturation activities in vitro. Lipids 34:965-969.

Cheva-Isarakul, B. 1992. Use of pigeon pea as animal feed 2. Digestibility of leaves and seeds in ruminants. J. Agric. 8:69-84.

Corriher, V. A., G. M. Hill, S. C. Phatak, and B. G. Mullinix Jr. 2007. Performance of beef heifers and digestibility of steers fed whole cotton seed, corn gluten feed and pigeon peas. J. Anim. Sci. 85(Suppl. 1):617. (Abstr.)

Dixon, R. M., and B. J. Hosking. 1992. Nutritional value of grain legumes for ruminants. Nutr. Res. Rev. 5:19-43.

Duckett, S. K., J. G. Andrae, and F. N. Owens. 2002. Effect of high-oil corn or added corn oil on ruminal biohydrogenation of fatty acids and conjugated linoleic acid formation in beef steers fed finishing diets. J. Anim. Sci. 80:3353-3360.

Duke, J. A. 1981. Handbook of Legumes of World Economic Importance. Plenum Press, New York.

Erwin, E. S., G. J. Marco, and E. M. Emery. 1961. Volatile fatty acid analyses of blood and rumen fluid by gas chromatograph. J. Dairy Sci. 44:1768-1771.

Gerson, T. A. J., and A. S. D. King. 1985. The effects of dietary starch and fibre on the in vitro rates of lipolysis and hydrogenation by sheep rumen digesta. J. Agric. Sci. (Camb.) 105:27-30.

Griinari, J. M., D. A. Dwyer, M. A. McGuire, D. E. Bauman, D. L. Palmquist, and K. V. Nurmela. 1998. Trans-octadecenoic acids and milk fat depression in lactating dairy cows. J. Dairy Sci. $81: 1251-1261$.

Griinari, J. M., K. Nurmela, D. A. Dwyer, D. M. Barbano, and D. E. Bauman. 1999. Variation of milk fat concentration of conjugated linoleic acid and milk fat percentage is associated with a change in ruminal biohydrogenation. J. Anim. Sci. 77(Suppl. 1):117-118. (Abstr)

Harfoot, C. G., and G. P. Hazlewood. 1997. Lipid metabolism in the rumen. Page 382 in the Rumen Microbial Ecosystem. 2nd ed. P. N. Hobson and C. S. Stewart, ed. Blackie Academic \& Professional, New York, NY.

Hill, G. M., S. C. Phatak, and B. G. Mullinix Jr.. 2006. Pigeon pea digestibility and utilization by growing beef calves. J. Anim. Sci. 84(Suppl. 1):111. (Abstr)

Jiang, J., L. Bjoerck, R. Fonden, and M. Emanuelson. 1996. Occurrence of conjugated cis-9, trans-11 octadecadienoic acid in bovine milk: Effects of feed and dietary regimen. J. Dairy Sci. 79:438-445.

Kelly, M. L., J. R. Berry, D. A. Dqyer, J. M. Griinari, P. Y. Chouinard, M. E. Van Amburgh, and D. E. Bauman. 1998a. Dietary fatty acid sources affect conjugated linoleic acid concentrations in milk from lactating dairy cows. J. Nutr. 128:881-885.

Kelly, M. L., E. S. Kolver, D. E. Bauman, M. E. Van Amburgh, and L. D. Muller. 1998b. Effect of intake of pasture on concentrations of conjugated linoleic acid in milk of lactating dairy cows. J. Dairy Sci. 81:1630-1636.

Latham, M. J., J. E. Storry, and M. E. Sharpe. 1972. Effect of lowroughage diets on the microflora and lipid metabolism in the rumen. Appl. Microbiol. 24:871-877.

Leat, W. M. F., P. Kemp, R. J. Lysons, and T. J. L. Alexander. 1977. Fatty acid composition of depot fats from gnotobiotic lambs. J. Agric. Sci. Camb. 88:175-179.

Lee, K. N., M. W. Pariza, and J. M. Ntambi. 1998. Conjugated linoleic acid decreases hepatic stearoyl-CoA desaturase mRNA expression. Biochem. Biophys. Res. Commun. 248:817-821.

Martin, S. A., and T. C. Jenkins. 2002. Factors affecting conjugated linoleic acid and trans-C18:1 fatty acid production by mixed ruminal bacteria. J. Anim. Sci. 80:3347-3352.

Nene, Y. L., and V. K. Sheila. 1990. Pigeonpea: Geography and importance. Pages 1-14 in The Pigeonpea. Y. L. Nene, S. H. Hall and V. K. Sheila, ed. CAB Int., Univ. Press, Cambridge, UK.

Orskov, E. R., and C. Fraser. 1975. The effects of processing of barleybased supplements on rumen $\mathrm{pH}$, rate of digestion and voluntary intake of dried grass in sheep. Br. J. Nutr. 34:493-500.

Owens, F. N., and A. L. Goetsch. 1988. Ruminal Fermentation. Pages 145-171 in The Ruminant Animal: Digestive, Physiology and Nutrition. D. C. Church, ed. Waveland Press, Inc., Prospect Heights, IL.

Park, P. W., and R. E. Goins. 1994. In Situ Preparation of FAME for analysis of fatty acid composition in foods. J. Food Sci. 59:12621266 .

Reed, J. D. 1995. Nutritional toxicology of tannins and related polyphenols in forage legumes. J. Anim. Sci. 73:1516-1528.

SAS Institute. 2003. Statistical Analysis System. Version 9.1. SAS Institute Inc., Cary, NC.

Smith, K. L. 1996. Standards for somatic cells in milk: Physiological and Regulatory. Page 7 in International Dairy Federation Mastitis Newsletter, September. International Dairy Federation, Brussels, Belgium.

Tangtaweewipat, S., and R. Elliot. 1989. Nutritional value of pigeon pea (Cajanus cajan) meal in poultry diets. Anim. Feed Sci. Technol. 25:123-135.

Van Soest, P. J. 1994. Nutritional Ecology of the Ruminant. 2nd ed. Cornell Univ. Press, Ithaca, NY.

Van Soest, P. J., J. B. Robertson, B. A. Lewis, and D. E. Akin. 1991 Methods for dietary fiber, neutral detergent fiber, nonstarch polysaccharides in relation to animal nutrition. J. Dairy Sci. 74:35833597.

Visitpanich, T., E. S. Batterham, and B. W. Norton. 1985. Nutritional value of chickpea (Cicer arietinum) and pigeon pea (Cajanus cajn) meals for growing pigs and rats. I. Energy content and protein quality. Aust. J. Agric. Res. 36:327-335.

Woodford, J. A., N. A. Jorgensen, and G. P. Barrington. 1986. Impact of dietary fiber and physical form on performance of lactating dairy cows. J. Dairy Sci. 69:1035-1047.

Zinn, R. A., and F. N. Owens. 1980. Influence of roughage level and feed intake level on digestive function. Oklahoma State Univ. Anim. Sci. Res. Rep. MP-107:150. Oklahoma State University, Stillwater. 